\title{
Species diversity and quantitative distribution of the surgeon fishes (Family: Acanthuridae) along Aqaba Gulf, Red Sea, Egypt.
}

\author{
Magdy A. Alwany \\ Department of Marine Science, Faculty of Science, Suez Canal University, \\ Ismailia, Egypt \\ (e-mail magdy.elalwany@yahoo.com)
}

\begin{abstract}
$\mathrm{T}$ his study aims to estimate the diversity and distribution of surgeon fishes (Acanthuridae) on reef flat and slope along Aqaba Gulf, Red Sea. The inner reef flat of Aqaba Gulf is characterized by high non-living substrate, whereas at the middle reef the contributions of living materials are flourished with algae. On the other hand, the outer reef flat and slope are characterized by welldeveloped coral communities. On the Egyptian coast of Aqaba Gulf, the total number of the surgeon fish was 8 species (Acanthurus gahhm, A. nigrofuscus, A. sohal, Ctenochaetus striatus, Naso lituratus, N. unicornis, Zebrasoma desjardinii and $Z$. xanthurum). A. nigrofuscus and $C$. striatus were abundant at most sites. The southern sites have the highest number of species, while the northern ones were the lowest. The patterns of habitats play a role in the species distribution of the acanthurids; some preferred the reef flat (A. nigrofuscus, $A$. sohal and C. striatus), while others preferred the reef slope (A. gahhm, $N$. lituratus, $N$. unicornis, $Z$. desjardinii and $Z$. xanthurum). Most acanthurids have territories on reefs. A. sohal has large territories on outer reef flat. An analysis of the fish fauna confirmed that there are differences between northern and southern parts of Aqaba Gulf in terms of fish assemblages.
\end{abstract}

Key words: abundance, diversity, surgeon fishes, Gulf of Aqaba, Red Sea

\section{INTRODUCTION}

Fishes are one of the most important marine resources on coral reef ecosystems (Letourneur et al., 1999). Surgeon fishes (Acanthuridae) are an important group of reef fishes, due to their herbivorous impact on reef ecology (Carpenter, 1986) and their popularity as aquarium fish (Tilghman et al., 2001). Acanthurids are extremely abundant tropical and subtropical marine fish, and often found on or near coral reefs or rocky areas (Choat and Bellwood, 1991). Most of the species are herbivorous; they graze diurnally on benthic algae and some species feed on detritus, whereas others are zooplankton feeders (Hobson, 1974). Herbivores exert profound influences over structure and function of benthic communities in shallow tropical marine environments (Robertson et al., 1979; Hixon, 1986). 
An important goal of reef fish ecology is to determine the processes that are important in the structure reef fish assemblages (Doherty and Williams, 1988; Williams, 1991). Population density of surgeon fishes was investigated by several studies (Robertson et al., 1979; Russ, 1984; Lewis and Wainwright, 1985; Robertson, 1988 \& 1991; Ahmed et al., 2003; Alwany and Stachowitsch, 2007). Family Acanthuridae comprises 6 genera containing 80 species, Naso (19 species), Prionurus (7 species), Paracanthurus (one species), Zebrasoma (7 species), Acanthurus (37 species), and Ctenochaetus (9 species) (Randall, 2002). Randall (1983) reported 11 species of surgeon fishes in the Red Sea. Dor (1984) and Gorn and Dor (1994) reported 16 species of surgeon fishes, without descriptive information. Reef habitats may be subdivided into distinct zones based on depth, aspect and exposure (Done, 1982; Williams, 1982). Patterns of zonation of coral reef fishes have been reviewed briefly by Sale (1980). The distribution patterns of herbivorous fishes were described by Williams and Hatcher (1983) and Russ (1985). The descriptions of zonation in many studies are often not quantitatively rigorous. Moreover, Aqaba Gulf is a model, in a small scale, of the Red Sea itself (Head, 1987). Their shores are dominated by coral reefs, mangle and seagrasses beds habitats that constitute a series of closely adjacent and often interdependent ecosystems (Ogden and Gladfelter, 1983). Thus, the objectives of this study were to describe spatial patterns of quantitative distribution and abundance of surgeon fishes along different reef habitats along Aqaba Gulf of the Red Sea. This inventory will serve as baseline data for future comparisons between different areas.

\section{Study area}

\section{MATERIALS AND METHODS}

Ten different geographical reefs were investigated along the Egyptian Aqaba Gulf coast of the Red Sea, spanning a distance of 265 km (Fig. 1). The study area covered the reef flat $(0.5-1 \mathrm{~m})$ and reef slope until $10 \mathrm{~m}$ depth. The reef type varied from coastal, island and barrier reefs (Table 1). The physical parameters such as wave actions, current and transparences of water were recorded.

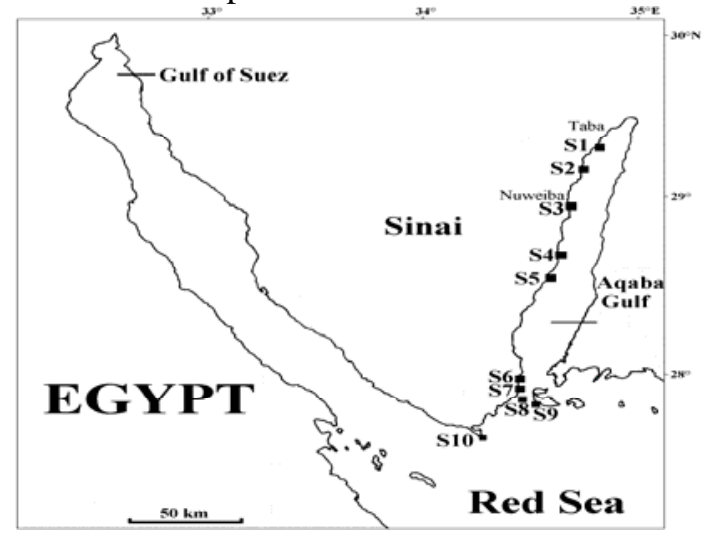

Fig.1: Map of Aqaba Gulf showing the location of the different sites. 
Table 1. List of sites showing their locations, reef type (R.T.), physical conditions (Ph.C.) and brief description of reef flat and reef slope along the Egyptian Aqaba Gulf coast. $(\mathrm{C}=$ coastal, $\mathrm{I}=$ island, $\mathrm{B}=$ barrier, $\mathrm{WA}=$ wave action, $\mathrm{TW}=$ turbid water, $\mathrm{CU}=$ current, $\mathrm{CM}=$ calm).

\begin{tabular}{|c|c|c|c|}
\hline Sites \& Location & R.T. & Ph.C. & Brief description \\
\hline $\begin{array}{l}\text { S1. Beer Sweer } \\
-29^{\circ} 08^{\prime} \mathrm{N} \\
-34^{\circ} 41^{\prime} \mathrm{E}\end{array}$ & $\mathrm{C}$ & TW & $\begin{array}{l}\text { Reef flat (20-30 m wide) is rich in algae and drafted leaves of } \\
\text { seagrasses. Reef slope not true and consisted of scattered coral } \\
\text { colonies and patches. }\end{array}$ \\
\hline $\begin{array}{l}\text { S2. Maganah } \\
-29^{\circ} 02^{\prime} \mathrm{N} \\
-34^{\circ} 40^{\prime} \mathrm{E}\end{array}$ & C & $\begin{array}{l}\text { weak } \\
\text { WA }\end{array}$ & $\begin{array}{l}\text { Both reef flat ( } 20-50 \text { m wide) and slope (relatively steep) are } \\
\text { well-developed coral communities. }\end{array}$ \\
\hline $\begin{array}{l}\text { S3. Newiubaa } \\
-28^{\circ} 56^{\prime} \mathrm{N} \\
-34^{\circ} 39^{\prime} \mathrm{E}\end{array}$ & C & $\begin{array}{l}\text { TW + } \\
\text { weak } \\
\text { WA }\end{array}$ & $\begin{array}{l}\text { Reef flat (30-40 m wide) is rich in algae and sea urchins, while } \\
\text { reef slope (gentle) is rich in corals colonies. }\end{array}$ \\
\hline $\begin{array}{l}\text { S4. Canyon } \\
-28^{\circ} 36^{\prime} \mathrm{N} \\
-34^{\circ} 30^{\prime} \mathrm{E}\end{array}$ & C & $\begin{array}{l}\text { strong } \\
\text { WA }\end{array}$ & $\begin{array}{l}\text { Reef flat ( } 30-50 \text { m wide) is rich in algae and coral colonies. } \\
\text { Reef slope (relatively steep) is well-developed corals. }\end{array}$ \\
\hline $\begin{array}{l}\text { S5. El-Masbat } \\
-28^{\circ} 32^{\prime} \mathrm{N} \\
-34^{\circ} 29^{\prime} \mathrm{E}\end{array}$ & C & $\begin{array}{l}\text { strong } \\
\text { WA }\end{array}$ & $\begin{array}{l}\text { Reef flat ( } 30-40 \text { m wide) is rich in algae, echinoderms and } \\
\text { rocks. Reef slope (relatively steep) is well-developed coral } \\
\text { communities. }\end{array}$ \\
\hline $\begin{array}{l}\text { S6. Ras Tantur } \\
-27^{\circ} 59^{\prime} \mathrm{N} \\
-34^{\circ} 22^{\prime} \mathrm{E}\end{array}$ & C & $\begin{array}{l}\text { strong } \\
\text { WA }\end{array}$ & $\begin{array}{l}\text { Both reef flat (40-50 m wide) and slope (relatively steep) are } \\
\text { well-developed coral communities. }\end{array}$ \\
\hline $\begin{array}{l}\text { S7. Ras Nassrani } \\
-27^{\circ} 58^{\prime} \mathrm{N} \\
-34^{\circ} 23^{\prime} \mathrm{E}\end{array}$ & C & $\begin{array}{l}\text { strong } \\
\text { WA }\end{array}$ & $\begin{array}{l}\text { Reef flat (50-70 m wide) is rich in corals and algae. Reef slope } \\
\text { (relatively steep) is well-developed coral communities. }\end{array}$ \\
\hline $\begin{array}{l}\text { S8. Jordan Reef } \\
-27^{\circ} 58^{\prime} \mathrm{N} \\
-34^{\circ} 25^{\prime} \mathrm{E}\end{array}$ & I & $\begin{array}{l}\text { strong } \\
\text { CU }\end{array}$ & $\begin{array}{l}\text { Reef flat (30-60 m wide) is rich in corals and algae. Reef slope } \\
\text { (steep) is well-developed coral communities. }\end{array}$ \\
\hline $\begin{array}{l}\text { S9. Shoper Reef } \\
-27^{\circ} 58^{\prime} \mathrm{N} \\
-34^{\circ} 26^{\prime} \mathrm{E}\end{array}$ & B & $\mathrm{CM}$ & $\begin{array}{l}\text { Reef flat ( } 20-30 \text { m wide) is rich by algae and echinoderms, } \\
\text { while reef slope (gentle) is rich in corals and algae. }\end{array}$ \\
\hline $\begin{array}{l}\text { S10. Ras } \\
\text { Mohammed } \\
-27^{\circ} 43^{\prime} \mathrm{N} \\
-34^{\circ} 15^{\prime} \mathrm{E} \\
\end{array}$ & C & $\begin{array}{l}\text { strong } \\
\text { WA }\end{array}$ & $\begin{array}{l}\text { Both reef flat ( } 30-60 \text { m wide) and slope (steep) are well- } \\
\text { developed coral communities. }\end{array}$ \\
\hline
\end{tabular}

\section{Field studies}

Underwater visual census techniques have been used to record fish densities and abundances on reefs since fifty years ago (e.g. Brock, 1954) and form the basis for population ecology studies and management decisions (Harmelin-Vivien et al., 1985). Furthermore, they provide rapid estimates of the relative abundance and distribution of reef fishes (Samoilys and Carlos, 2000). Here, members of the surgeon fishes were counted using this approach along transects $\left(100 \mathrm{~m} \mathrm{X} 6 \mathrm{~m} \mathrm{X} 1 \mathrm{~m}=600 \mathrm{~m}^{3}\right)$ on the reef flat (RF, depth: 0.5-1 m) and reef slope (RS, depth: 1-10 m). Transect width was estimated visually, and time used to estimate the length of transect, so as to avoid the disturbance to fishes that occurs when a line is laid. On the reef flat, fishes were observed using snorkeling, on the reef slope using SCUBA during day-time from 1100 to $1400 \mathrm{~h}$. 


\section{Data analysis}

The data were analysed statistically using the software packages PRIMER (V 5.0) and SPSS (V 12). Species richness was expressed by considering the number of species (D), and species diversity and homogeneity were determined using the Shannon-Wiener diversity index $\left(\mathrm{H}^{\prime}\right)$ and the evenness index ( $\mathrm{J}^{\prime}$ ) (Pielou, 1966). One-way ANOVA was carried out with SPSS program. These parameters were calculated for each site by pooling data from the sample replicates. When necessary, abundance data were square root transformed to produce normality and homogeneity of variance.

\section{RESULTS}

\section{General description of study area}

The Egyptian coast of Aqaba Gulf consists of a network of three distinct units linked by protected coastlines, thereby creating a continuous length of protected shorelines on the Aqaba Gulf stretching from Taba to Ras Mohammed at southern extremity of the Sinai Peninsula. The inner reef flat is characterized by high non-living substrate (about $90 \%$ ), whereas at the middle reef, the contribution of living materials is mainly flourished by algae. On the other hand, the outer reef flat and slope are characterized by well-developed coral communities. Along Aqaba Gulf, the coral communities comprised many soft and hard corals. Soft coral colonies are mainly Labophytum, Nephthyia, Sinularia, Cladiella and Sarcophyton, whereas, the hard corals are represented on reefs by Acropora, Pocillopora, Favites, Favia, Porites, Pavona, Stylophora and Montipora. Non-true corals are represented by Millepora and Tubipora. Some invertebrates, such as mollusks, echinoderms and crustaceans, were recorded. They were represented by bivalves (e.g. Tridacna sp.) and gastropods (e.g. Conus sp.); by Echinometra and Diadema, and by different species of crabs and shrimps, respectively. Many genera of turf algae are dominated in the study area along Aqaba Gulf such as brown algae (Dictyota, Padina and Pocockiella) and red algae (Laurencia, Polysiphonia, Jania, Hypnea and Herposiphonia).

\section{General distribution and abundance of surgeon fishes}

Table (2) shows the list and number of surgeon fish species at reef flat and slope along Aqaba Gulf coast. In general, the total number of species was 8 species (Acanthurus gahhm, A. nigrofuscus, A. sohal, Ctenochaetus striatus, Naso lituratus, N. unicornis, Zebrasoma desjardinii and Z. xanthurum). All acanthurids are active during the day and spend much of their time feeding. At sunset, they stop feeding and seek hiding places between reef holes. $A$. nigrofuscus and $C$. striatus were the most abundant at most sites $(27.0 \pm 1.8$ fish/600 $\mathrm{m}^{3}$ and 16.5 $\pm 7.0 \mathrm{fish} / 600 \mathrm{~m}^{3}$, respectively). Site 10 (Ras Mohammed, at south) has the highest number of species (8 species), while site 3 (Newiubaa, at north) has the lowest number of species (4 species). A. gahhm, Naso lituratus and $N$. unicornis are the lowest in abundance along Aqaba Gulf $(0.6 \pm 0.8$ fish/600 $\mathrm{m}^{3}, 2.5 \pm 0.1 \mathrm{fish} / 600 \mathrm{~m}^{3}$ and $0.7 \pm 0.9 \mathrm{fish} / 600 \mathrm{~m}^{3}$, respectively). One- 
way ANOVA showed that the influence of species is highly significant ( $\mathrm{p}<$ 0.001 , Table, 3), but the influence of sites was not significant ( $\mathrm{p}=0.197)$.

\section{Habitat distribution and diversity}

Based on the number of species, the pattern of habitat preferences is clear in the distribution of Acanthuridae along Aqaba Gulf coast (Fig., 2). Some acanthurids preferred the reef flat (Acanthurus nigrofuscus, A. sohal and Ctenochaetus striatus), while others preferred the reef slope (A. gahhm, Naso lituratus, N. unicornis, Zebrasoma desjardinii and Z. xanthurum). Based on the number of individuals, the reef flat comprised $53.6 \%$ of the total acanthurids population while the slope comprised $46.4 \%$ of population. One-way ANOVA showed that the distribution of surgeonfishes did not differ significantly among the reef zones ( $p=0.550$, Table, 3 ). Most acanthurid species have territories on reefs. A. sohal has large territories on outer reef flat, where it preferred this zone along the Red Sea.

Table 2. The mean abundance (mean \pm SD) of each species to the surgeonfishes on the reef flat and reef slope at different ten sites along Aqaba Gulf coast in the northern Red Sea.

\begin{tabular}{|c|c|c|c|c|c|c|c|c|c|c|}
\hline Species & $\begin{array}{l}\text { North } \\
\text { Site } 1\end{array}$ & Site 2 & Site 3 & Site 4 & Site 5 & Site6 & Site 7 & Site 8 & Site 9 & $\begin{array}{l}\text { South } \\
\text { Site } 10\end{array}$ \\
\hline $\begin{array}{l}\text { Reef flat } \\
\text { Acanthurus } \\
\text { gahhm }\end{array}$ & 0 & 0 & 0 & 0 & 0 & 0 & 0 & 0 & 0 & 0 \\
\hline A. nigrofuscus & $7.7 \pm 2.1$ & $45.3 \pm 4.9$ & $16.7 \pm 3.5$ & $19.7 \pm 7.4$ & $9.3 \pm 1.5$ & $66.7 \pm 20.2$ & $13.3 \pm 4.5$ & $32.7 \pm 5.7$ & $33.3 \pm 4.0$ & $38.0 \pm 2.0$ \\
\hline A. sohal & $1.7 \pm 0.6$ & $9.7 \pm 4.0$ & 0 & $1.0 \pm 1.0$ & $3.7 \pm 1.5$ & $6.7 \pm 2.1$ & $0.3 \pm 0.6$ & $2.3 \pm 2.5$ & $9.0 \pm 3.6$ & $17.7 \pm 3.5$ \\
\hline $\begin{array}{l}\text { Ctenochaetus } \\
\text { striatus }\end{array}$ & $4.3 \pm 1.5$ & $54.3 \pm 7.1$ & $4.0 \pm 1.0$ & $22.0 \pm 3.6$ & $15.0 \pm 5.2$ & $19.3 \pm 4.2$ & $17.7 \pm 8.1$ & $21.3 \pm 3.2$ & $30.0 \pm 2.0$ & $26.3 \pm 7.1$ \\
\hline Naso lituratus & 0 & 0 & 0 & 0 & 0 & 0 & $2.7 \pm 1.2$ & $7.3 \pm 1.5$ & $4.0 \pm 2.0$ & $10.0 \pm 4.0$ \\
\hline$N$. unicornis & 0 & 0 & 0 & 0 & 0 & 0 & 0 & 0 & 0 & $0.3 \pm 0.6$ \\
\hline $\begin{array}{l}\text { Zebrasoma } \\
\text { desjardinii }\end{array}$ & $5.0 \pm 1.0$ & $5.3 \pm 2.5$ & $0.7 \pm 1.2$ & $11.0 \pm 2.0$ & $0.7 \pm 1.2$ & $4.7 \pm 1.2$ & $8.7 \pm 3.5$ & $9.3 \pm 1.5$ & $9.3 \pm 1.5$ & $13.7 \pm 2.1$ \\
\hline Z. xanthurum & $3.0 \pm 1.0$ & $7.3 \pm 3.2$ & $4.3 \pm 1.5$ & $9.3 \pm 4.2$ & $11.3 \pm 2.5$ & $1.3 \pm 0.6$ & $4.0 \pm 2.6$ & $3.7 \pm 3.5$ & $26.3 \pm 4.7$ & $15.7 \pm 3.2$ \\
\hline \begin{tabular}{l}
\multicolumn{1}{c}{ Reef slope } \\
Acanthurus \\
gahhm
\end{tabular} & 0 & 0 & 0 & 0 & 0 & 0 & 0 & $0.3 \pm 0.6$ & $0.7 \pm 1.2$ & $10.3 \pm 6.5$ \\
\hline A. nigrofuscus & $9.7 \pm 2.1$ & $15.7 \pm 3.5$ & $56.7 \pm 6.0$ & $65.0 \pm 5.6$ & $2.0 \pm 2.0$ & $20.7 \pm 3.1$ & $5.3 \pm 1.5$ & $15.0 \pm 6.2$ & $8.0 \pm 2.0$ & $11.7 \pm 2.5$ \\
\hline A. sohal & $0.3 \pm 0.6$ & $4.0 \pm 2.0$ & 0 & 0 & $0.7 \pm 0.6$ & $2.3 \pm 1.5$ & 0 & 0 & $1.0 \pm 1.0$ & $0.3 \pm 0.6$ \\
\hline $\begin{array}{l}\text { Ctenochaetus } \\
\text { striatus }\end{array}$ & $4.7 \pm 2.1$ & $19.3 \pm 5.5$ & $9.3 \pm 1.5$ & $35.0 \pm 6.2$ & 0 & $15.7 \pm 5.0$ & $2.3 \pm 2.1$ & $8.3 \pm 2.1$ & $9.3 \pm 2.5$ & $11.7 \pm 4.0$ \\
\hline Naso lituratus & 0 & 0 & 0 & $1.0 \pm 0$ & $3.7 \pm 0.6$ & $3.7 \pm 2.1$ & $3.3 \pm 1.5$ & $3.7 \pm 1.5$ & $4.3 \pm 0.6$ & $6.3 \pm 2.5$ \\
\hline N. unicornis & $1.0 \pm 1.0$ & $0.7 \pm 0.6$ & 0 & $2.3 \pm 0.6$ & $2.0 \pm 1.0$ & $2.7 \pm 1.2$ & $0.3 \pm 0.6$ & $1.0 \pm 1.0$ & $0.3 \pm 0.6$ & $2.3 \pm 0.6$ \\
\hline $\begin{array}{l}\text { Zebrasoma } \\
\text { desjardinii }\end{array}$ & $13.0 \pm 2.6$ & $6.7 \pm 2.1$ & $1.6 \pm 0.6$ & $17.3 \pm 3.5$ & $6.3 \pm 2.1$ & $12.0 \pm 2.0$ & $9.0 \pm 3.6$ & $16.3 \pm 4.5$ & $6.7 \pm 1.2$ & $10.0 \pm 3.0$ \\
\hline Z. xanthurum & $17.3 \pm 3.8$ & $2.7 \pm 0.6$ & $17.7 \pm 1.5$ & $60.3 \pm 2.1$ & $7.3 \pm 2.1$ & $24.0 \pm 5.0$ & $2.7 \pm 3.1$ & $6.3 \pm 2.1$ & $4.7 \pm 2.1$ & $5.0 \pm 1.0$ \\
\hline
\end{tabular}




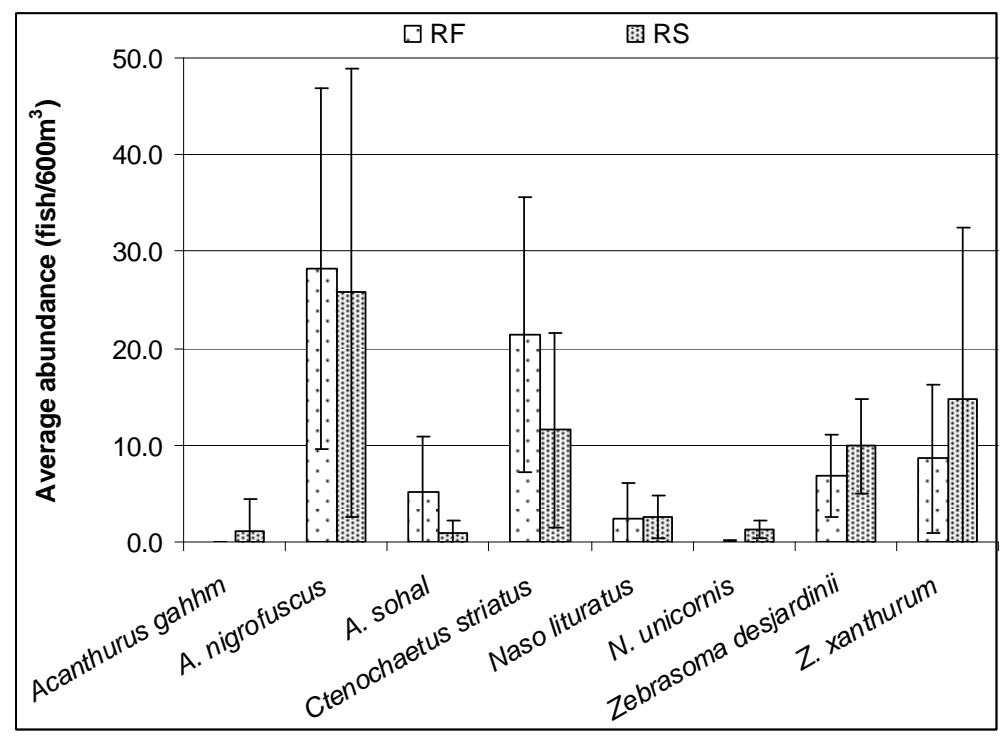

Fig. 2. Average abundance of surgeonfish species on the reef flat (RF) and slope (RS) along Aqaba Gulf.

Table 3: Results of one-way ANOVA performed on abundance of surgeonfishes $(* *=$ at $1 \%$ significance level)

\begin{tabular}{|l|l|c|c|c|c|}
\hline Factor & Source of variation & df & MS & F value & P value \\
\hline \multirow{3}{*}{ Sites } & between groups & 9 & 222.46 & 1.392 & 0.197 \\
& within groups & 150 & 159.87 & & \\
& total & 159 & & & \\
\hline \multirow{3}{*}{ Zones } & between groups & 1 & 58.81 & 0.358 & 0.550 \\
& within groups & 158 & 164.07 & & \\
& total & 159 & & & \\
\hline \multirow{3}{*}{ Species } & between groups & 7 & 1498.73 & 14.705 & $0.001^{* *}$ \\
& within groups & 152 & 101.92 & & \\
& total & 159 & & & \\
\hline
\end{tabular}

On reef flat, the average species richness ranged from 0.833 at site 2 to 1.301 at site 7 . The highest evenness index $\left(\mathrm{J}^{\prime}\right)$ was recorded at site $1(0.931)$, while site 6 has the lowest value (0.602). Average Shannon-Wiener diversity $\left(\mathrm{H}^{\prime}\right)$ varied between 0.965 at site 3 and 1.706 at site 10 (Table 4). On reef slope, the average species richness ranged from 0.675 at site 3 to 1.969 at site 9 . The highest evenness index $\left(\mathrm{J}^{\prime}\right)$ was recorded at site $10(0.901)$, while site 3 yielded the lowest value (0.661). Average Shannon-Wiener diversity $\left(\mathrm{H}^{\prime}\right)$ varied between 0.917 at site 3 and 1.873 at site 10 (Table 4). The Bray-Curtis similarity 
index cluster analysis of the reef flat and slope according to fish abundance is shown in fig. 3 A \& B. This analysis confirmed that there are differences between northern and southern parts of Aqaba Gulf. On reef flat, the dendrogram revealed three main groups (Fig. 3A); the first group comprises three sites at northern Aqaba Gulf (sites 1, 3 and 5); the second includes four sites at the south (sites 7, 8, 9 and 10) and one site at the north (site 4); whereas the third group includes two sites (sites 2 and 6) from the north and south. On the other hand, the cluster analysis based on fish abundance on the reef slope (Fig. 3B) revealed four main groups; the first group comprises four sites at southern Aqaba Gulf (sites 7, 8, 9 and 10); the second includes two sites in the north (site 3 and 4); the third includes three site in the north (sites 1, 2 and 6); whereas the fourth group includes one site (site 5).

Table 4. Fish community parameters of diversity indices: number of species (S); number of individuals (I); Species richness (D); Evenness $\left(\mathrm{J}^{\prime}\right)$; Shannon-Wiener $\left(\mathrm{H}^{\prime}\right)$ on reef flat and slope.

\begin{tabular}{|l|c|c|c|c|c|c|c|c|c|c|}
\hline \multirow{2}{*}{ Sites } & \multicolumn{9}{|c|}{ Reef flat } & \multicolumn{6}{|c|}{ Reef slope } \\
\cline { 2 - 12 } & $\mathrm{S}$ & $\mathrm{I}$ & $\mathrm{D}$ & $\mathrm{J}^{\prime}$ & $\mathrm{H}^{\prime}$ & $\mathrm{S}$ & $\mathrm{I}$ & $\mathrm{D}$ & $\mathrm{J}^{\prime}$ & $\mathrm{H}^{\prime}$ \\
\hline Site 1 & 5 & 22 & 1.300 & 0.931 & 1.499 & 6 & 46 & 1.306 & 0.784 & 1.404 \\
\hline Site 2 & 5 & 122 & 0.833 & 0.767 & 1.235 & 6 & 49 & 1.285 & 0.795 & 1.424 \\
\hline Site 3 & 4 & 26 & 0.924 & 0.696 & 0.965 & 4 & 85 & 0.675 & 0.661 & 0.917 \\
\hline Site 4 & 5 & 63 & 0.966 & 0.860 & 1.384 & 6 & 181 & 0.962 & 0.760 & 1.361 \\
\hline Site 5 & 5 & 40 & 1.084 & 0.840 & 1.352 & 6 & 22 & 1.618 & 0.874 & 1.565 \\
\hline Site 6 & 5 & 99 & 0.871 & 0.602 & 0.969 & 7 & 81 & 1.365 & 0.855 & 1.664 \\
\hline Site 7 & 6 & 47 & 1.301 & 0.808 & 1.448 & 6 & 23 & 1.596 & 0.854 & 1.529 \\
\hline Site 8 & 6 & 77 & 1.152 & 0.810 & 1.452 & 7 & 51 & 1.526 & 0.811 & 1.579 \\
\hline Site 9 & 6 & 112 & 1.060 & 0.883 & 1.583 & 8 & 35 & 1.969 & 0.844 & 1.754 \\
\hline Site 10 & 7 & 122 & 1.250 & 0.877 & 1.706 & 8 & 58 & 1.726 & 0.901 & 1.873 \\
\hline
\end{tabular}




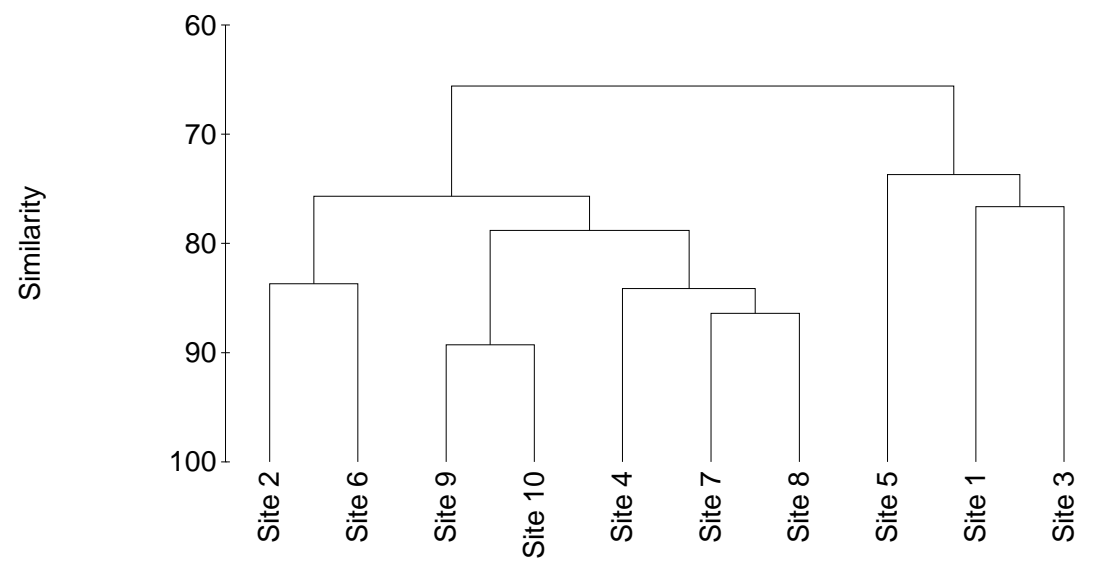

\section{( A)}

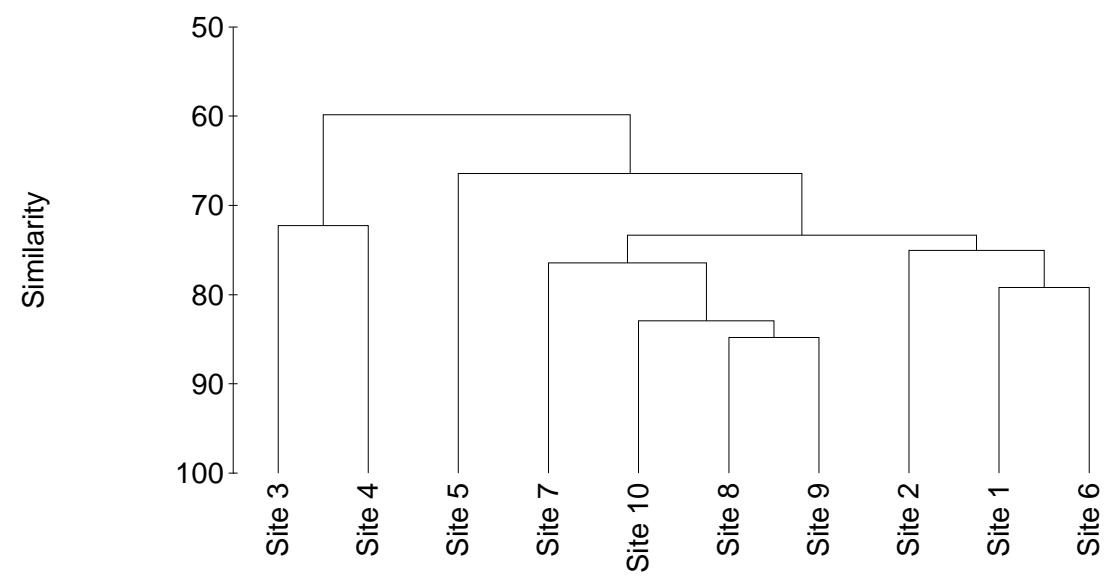

( B )

Fig. 3. Cluster analysis (Bray-Curtis similarity, square root transformation, group average) showing associations of 10 sites on the reef flat (A) and slope (B) along Aqaba Gulf.

\section{DISCUSSION}

Local populations of marine reef fishes often show great spatial variation in abundance (Holbrook et al., 2000). This variation results from a combination of many physical and biological factors that affect fish distribution and diversity. The density and distribution of many species of coral reef fishes 
are strongly associated with habitat characteristics (Luckhurst and Luckhurst, 1978; Bell and Galzin, 1984; Chapman and Kramer, 1999). Local diversity of coral reef fishes is generally correlated with the size of the reef (Galzin et al., 1994). (Acanthuridae) Surgeon fishes is one of seven families of fishes having an obligate association with coral reefs (Choat and Bellwood, 1991). In the present study, the total recorded number of species was 8 species along the Egyptian coast of Aqaba Gulf. This low species richness of surgeon fishes along Gulf of Aqaba, was generally lower than that observed on coral reefs elsewhere throughout the world (Alwany and Stachowitsch, 2007). The low diversity of acanthurids recorded in Aqaba Gulf may be attributed to recent historical origin of the Red Sea and Gulf of Aqaba.

Although many of the present species of Naso are consistently associated with coral reefs, with the exception of the smaller pelagic species, they are rarely abundant compared to Acanthurus and Ctenochaetus, which are abundant and closely associated with reef environments (Klanten et al., 2004). The present investigation confirms this finding in the Red Sea, where $A$. nigrofuscus and $C$. striatus were the most abundant at most sites $(27.0 \pm 1.8$ fish $/ 600 \mathrm{~m}^{3}$ and $16.5 \pm 7.0 \mathrm{fish} / 600 \mathrm{~m}^{3}$, respectively). Naso lituratus and $N$. unicornis are the lowest in abundance along Aqaba Gulf $\left(2.5 \pm 0.1\right.$ fish $/ 600 \mathrm{~m}^{3}$ and $0.7 \pm 0.9$ fish $/ 600 \mathrm{~m}^{3}$, respectively). Montgomery et al. (1989) reported that Zebrasoma xanthurum was more closely associated with coral reef habitats, which was similarly observed in the present study.

The species richness of the 6 families (Pomacentridae, Chaetodontidae, Acanthuridae, Labridae, Scaridae and Serranidae) was examined in the different regions of the northern Red Sea, Gulf of Suez and Gulf of Aqaba by Sheppard et al. (1992) and Alwany \& Stachowitsch (2007). They noted a decreasing number of species, from southern coast of Egypt to northern Aqaba Gulf. Our results revealed another decreasing of species number from southern to northern parts of Aqaba Gulf. In this study, 8 species were recorded from reef flat to $10 \mathrm{~m}$ depth. Khalaf and Kochzius (2002) reported 6 species of surgeon fishes on five coral reefs and seagrass-dominated Al-Mamlah Bay at the Jordanian coast at the northern Aqaba Gulf. This also confirmed the differences between southern and northern parts of Aqaba Gulf.

The assemblages of herbivorous fishes on reef flats tend to have relatively low numbers of species and individuals (Russ, 1984). Alwany and Gab-Alla (2006) reported the same finding for the northern Red Sea; where the number of species and individuals of many groups of reef fishes on the Egyptian reef flats are low compared to other reef habitats. Lecchini et al. (2003) and the present results did not support this finding for surgeon fishes in the Aqaba Gulf. Some species are abundant on reef flat (Acanthurus nigrofuscus, A. sohal and Ctenochaetus striatus), whereas others are abundant on reef slope (Acanthurus gahhm, Naso lituratus, N. unicornis, Zebrasoma desjardinii and Z. xanthurum). Some species of surgeon fishes (such as blue tangs: Acanthurus coeruleus) were 
observed in all zones of fringing reefs (Lawson et al., 1999; Chapman and Kramer, 1999) and could be move between these zones depending on free of habitat selection (Morgan, 2003). On the other hand, another species (such as sohal: Acanthurus sohal) have restricted zones on the outer reef flat (Alwany et al., 2005). Also, they stated that $A$. sohal spent most of their time swimming (patrolling) along the territory border, stopping briefly to feed on algae. The complexity of substrate and water movements at the outer reef flat also plays an important role in distribution of most surgeonfish species. The slope has more diverse communities, so it represented a good zone to most surgeonfishes.

The present study supports the view that most reef fish tend to be strongly site-attached. It would be erroneous to conclude, however, the strong site attachment necessarily implies small home ranges (Chapman and Kramer, 1999). Some species (e.g. A. sohal) tend to be strongly site-attached, while other species (e.g. tangs, Zebrasoma desjardinii and Z. xanthurum) are free to select their habitats. Movements between zones may depend on food seeking, the two Zebrasoma species achieve their highest bite rates in the fore flat reef zone (Alwany and Gab-Alla, 2006). Wandering tangs (Zebrasoma desjardinii and Z. xanthurum) visit cleaning stations where fishes remove ectoparasites (Morgan and Kramer, 2004), and it have been suggested that the main function of wandering from schools is to facilitate visits to such stations (Reinthal and Lewis, 1986). This would predict more frequent wandering in the outer reef flat and slope zone because the density of cleaning stations increases seaward. Wandering may occur in the morning because parasite loads are often higher at dawn (Grutter and Hendrikz, 1999); making visits to cleaning stations a priority in the early morning.

\section{ACKNOWLEDGEMENTS}

The author wish to thank Dr. Ali A. Gab-Alla in Department of Marine Sciences at the Suez Canal University for his effort in revision of this manuscript. This work would not have been possible without the kind assistance of the Department of Marine Science, Suez Canal University, Egypt.

\section{REFERENCES}

Ahmed, A.I.; Mohammed, S.Z.; Alwany, M.A. and Shraka, T.M., (2003). Distribution of surgeonfishes (Acanthuridae) in relation to the benthic substrates at Aqaba Bay in vicinity of Sharm El-Sheikh, Egyptian Red Sea. J. Egypt. Ger. Soc. Zool., 42 (B): 1-15.

Alwany, M.A. and Gab-Alla, A.F A. (2006). Feeding ecology of two congeneric herbivorous surgeonfishes on the reef flat of Sharm El-Sheikh, Red Sea, 
Egypt. J. Egypt. Acad. Soc. Environ. Develop., (D-Environmental Studies), 7(3): 75-89.

Alwany, M.A. and Stachowitsch, M. (2007). Distribution and diversity of six common reef fish families along the Egyptian coast of the Red Sea. J. Fish. Aqaut. Sci., 2(1): 1-16.

Alwany, M.A.; Thaler, E. and Stachowitsch, M. (2005). Territorial behaviour of Acanthurus sohal and Plectroglyphidodon leucozona on the fringing Egyptian Red Sea reefs. Environ. Biol. Fish., 72: 321-334.

Bell, J.D. and Galzin, R. (1984). Influence of live coral cover on coral reef fish communities. Mar. Ecol. Prog. Ser., 15: 265-274.

Brock, V.E. (1954). A preliminary report on a method of estimating reef fish populations. J. Wildl. Mgmt., 18: 297-308.

Carpenter, R.C. (1986). Partitioning herbivory and its effects on coral reef algal communities. Ecol. Monogr., 56: 345-363.

Chapman, M.R. and Kramer, D.L. (1999). Movements of fishes within and among fringing coral reefs in Barbados. Environ. Biol. Fish., 57: 11-24.

Choat, J.H. and Bellwood, D.R. (1991). Reef fishes: their history and evolution. In: Sale, P.F. (ed.) The ecology of fishes on coral reefs. Academic Press, San Diego, pp 39-60.

Doherty, P.J. and Williams, D.M.B. (1988). The replenishment of coral reef fish populations. Oceanogr. Mar. Biol., A. Rev., 26: 487-51.

Done, T.J. (1982). Patterns in the distribution of coral communities across the Great Barrier Reef. Coral Reefs, 1: 95-107.

Dor, M., (1984). Checklist of Red Sea fishes. Israel Academy of Sciences and Humanities, Jerusalem, 347 pp.

El-Sayed, A. A. M. (1987). Biological studies on Surgeonfishes (Acanthuridae) from the Red Sea. M.Sc. Thesis Al-Azhar University, Egypt, 299 pp.

Galzin, R.; Planes, S.; Dufour, V. and Salvat, B. (1994). Variation in diversity of coral reef fish between French Polynesian atolls. Coral Reefs, 13: 175180. 
Goren, M. and Dor, M. (1994). An updated checklist of the fishes of the Red Sea. Clofres II. The Israel Academy of Sciences and Humanities, Eilat, 120 pp.

Grutter, A.S. and Hendrikz, J. (1999). Diurnal variation in the abundance of parasitic gnathiid isopod larvae on coral reef fish: its implications in cleaning interactions. Coral Reefs, 18: 187-191.

Harmelin-Vivien, M.L.; Harmelin, J.G.; Chauvet, C.; Duval, C.; Galzin, R.; Lejeune; P.; Barnabé, G.; Blanc, F.; Ghevalier, R.; Duclerc, J. and Lasserre, G. (1985). Evaluation visuelle des peuplements et populations de poisons: methods et problemes. Rev. Ecol., 40: 468-539.

Head, S.M, (1987). Minor invertebrate groups. In: Edwards, A.J. and Head, S.M. (Eds.), Red Sea (Key Environments), Pergamon Press, Oxford, pp 233250.

Hixon, M.A. (1986). Fish predation and local prey diversity. In: Simenstad C. A. and G. M. Cailliet, (eds.), Contemporary studies on fish feeding, Dordrecht,pp 235-257.

Hobson, E.S. (1974). Feeding relationships of teleostean fishes on coral reef in Kona, Hawaii. U. S. Fish Bulletin, 72: 915-1031.

Holbrook, S.J.; Forrester, G.E. and Schmitt, R.J. (2000). Spatial patterns in abundance of a damselfish reflect availability of suitable habitat. Oecologia, 122: 109-120.

Khalaf, M.A. and Kochzius, M. (2002). Community structure and biogeography of shore fishes in the Gulf of Aqaba, Red Sea. Helgoland Mar. Res., 55: 252-284.

Klanten, S.O., Herwerden, L., Choat, J.H. and Blair, D., (2004). Patterns of lineage diversification in the genus Naso (Acanthuridae). Molecu. Phylogen. Evol., 32: 221-235.

Lawson, G.L., Kramer, D.L. and Hunte, W. (1999). Size-related habitat use and schooling behavior in two species of surgeonfish (Acanthurus bahianus and A. coeruleus) on a fringing reef in Barbados, West Indies. Env. Biol. Fish., 54: 19-33. 
Lecchini, D.; Adjeroud, M.; Pratchett, M.S.; Cadoret, L. and Galzin, R. (2003). Spatial structure of coral reef fish communities in the Ryukyu Islands, southern Japan. Oceanol. Acta, 26: 537-547.

Letourneur, Y.; Labrosse, P. and Kulbicki, M. (1999). Commercial fish assemblages on New Caledonian fringing reefs submitted to different levels of ground erosion. Oceanol. Acta, 22(6): 609-622.

Lewis, S.M. and Wainwright, P.C. (1985). Herbivore abundance and grazing intensity on a Caribbean coral reef. J. Exp. Mar. Biol. Ecol., 87: 215228.

Luckhurst, B.E. and Luckhurst. K. (1978). Analysis of the influence of substrate variables on coral reef fish communities. Mar. Biol., 49: 317-323.

Montgomery, W.L.; Myberg, A.A. and Fishelson, L. (1989). Feeding ecology of surgeonfishes (Acanthuridae) in the Northern Red Sea, with particular reference to Acanthurus nigrofuscus (Forsskal). J. Exp. Mar. Biol. Ecol., 132: 179-207.

Morgan, I.E. (2003). The behaviour and ecology in social organization of a Caribbean surgeonfish. M.Sc. Thesis. McGill University, 112 pp.

Morgan, I.E. and Kramer. D.L. (2004). The social organization of adult blue tangs, Acanthurus coeruleus, on a fringing reef, Barbados, West Indies. Environ. Biol. Fish., 71: 261-273.

Ogden, J.C. and Glafelter, E.H. (1983). Coral reefs, seagrass beds and mangroves: their interaction in coastal zones of the Caribbean. UNESCO Reports in Marine Science, No. 23.

Pielou, E.C. (1966). Shannon's formula as a measure of specific diversity. Its use and misuse. Am. Nat., 100: 463-465.

Randall, J.E. (1983). Red Sea reef fishes. IMMEL Publishing, London, 192 pp.

Randall, J.E. (2002). Surgeonfishes of Hawaii and the World. Mutual Publishing and Bishop Museum Press.

Reinthal, P.N. and Lewis, S.M. (1986). Social behaviour, foraging efficiency and habitat utilization in a group of tropical herbivorous fish. Anim. Behav., 34: 1687-1693. 
Robertson, D.R. (1988). Abundances of surgeonfishes on patch reefs in Caribbean Panama: due to settlement, or postsettlement events? Mar. Biol., 97: 495-501.

Robertson, D.R. (1991). Increases in surgeonfish populations after mass mortality of the sea urchin Diadema antillarum in Panama indicate food limitation. Mar. Biol., 111: 437-444.

Robertson, D.R.; Green D.G. and Victor, B.C. (1979). The behavioral ecology of three Indian Ocean surgeonfishes (Acanthurus lineatus, A. leucosternon and Zebrasoma scopas): their feeding strategies, and social and mating systems. Env. Biol. Fish., 4: 125-170.

Russ, G. (1984). Distribution and abundance of herbivorous grazing fishes in the central Great Barrier Reef. I. levels of variability across the entire continental shelf. Mar. Ecol. Prog. Ser., 20: 23-34.

Russ, G.R. (1985). Effects of protective management on coral reef fishes in the central Philippines. Proc. $5^{\text {th }}$ Int. Coral Reef Congr., 4: 219-224.

Sale, P.F. (1980). The ecology of fishes on coral reefs. Oceanography Marine Biology: An Ann. Rev., 18: 367-421.

Samoilys, M.A. and Carlos, G.M. (2000). Determining methods of underwater visual census for estimating the abundance of coral reef fishes. Environ. Biol. Fish., 57: 289-304.

Sheppard, C.; Price, A. and Roberts, C. (1992). Marine Ecology of the Arabian Region. Academic Press, London.

Tilghman, G.C.; Klinger-Bowen, R. and Francis-Floyd, R. (2001). Feeding electivity indices in surgeonfish (Acanthuridae) of the Florida Keys. Aqu. Sci. Conserv., 3: 215 -223.

Williams, D.McB. (1982). Patterns in the distribution of fish communities across the central Great Barrier Reef. Coral Reefs, 1: 35 - 43.

Williams, D.McB. (1991). Patterns and processes in the distribution of coral reef fishes. In: Sale, P.F. (ed.) The ecology of fishes on coral reefs. Academic Press, San Diego, pp 437- 474.

Williams, D.McB. and Hatcher, A.I. (1983). Structure of fish communities on outer slopes of inshore, mid-shelf and outer shelf reefs of the Great Barrier Reef. Mar. Ecol. Prog. Ser., 10: 239-250. 